\title{
A COMBINED QFD-GAHP TECHNIQUE TO TRANSLATE CUSTOMER REQUIREMENTS INTO THE PRODUCTION PROCESS OF MEAT PRODUCTS
}

\author{
Hossein Soheylinia $^{1 凶}$, Ali Husseinzadeh $\operatorname{Kashan}^{1}$, Saeid Soheyliniya ${ }^{3}$ \\ ${ }^{I}$ MSc Graduate in Industrial Engineering, Department of Industrial Engineering, Faculty of Industrial and \\ Systems Engineering, Tarbiat Modares University, Tehran, Iran; \\ Address: Department of Industrial Engineering, Room 910, Faculty of Engineering, Tarbiat \\ Modares University, Tehran, Iran, P.O.Box: 14115-111, /Phone: +98 218288 4398; \\ 2 Assistant Professor in Industrial Engineering, Department of Industrial Engineering, Faculty of \\ Industrial and Systems Engineering, Tarbiat Modares University, Tehran, Iran; \\ ${ }^{3}$ MSc in Microbiology, Department of Research and Development (R\&D), pak Taliseh industries, Karaj, Iran; \\ \.soheylinia@gmail.com \\ https://doi.org/10.34302/crpjfst/2020.12.5.13 \\ Article history: \\ Received: \\ 29 August 2020 \\ Accepted: \\ 25 December 2020 \\ Keywords: \\ Meat Products; \\ Customers' requirement; \\ Product development; \\ Quality Function Deployment; \\ Group Analytic Hierarchy \\ Process;

\begin{abstract}
Quality Function Deployment (QFD), as one of the quality engineering methods, tries to attract customer's satisfaction and produce a product suitable for the customers' needs. The aim of the present study is to describe the process of producing a meat product (hamburger) based on the customers' need defined on a higher quality level via combining quality function deployment (QFD) and group analytic hierarchy process (GAHP) techniques. At first, the target customers and what they need from a hamburger product were recognized. Then, using GAHP Method the relative weight of each requirement was calculated. The 4-matrix QFD model was used and the house of quality matrix, product design matrix, process design matrix, and process control planning matrix were completed based on technical principles and hygienic standards of meat product producing units. Among recognized customer requirements of hamburger quality, "not being harmful to body" is the most important requirement and "packed in different weights" is the least important one. Research findings indicates that improving the level of technical and engineering characteristics of "frozen meat" would have a significant effect on enhancing the quality of hamburger and consequently on the satisfaction of the customer. Further, it is necessary that in process design matrix, "microbial test of meat" and "microbial test of semi-processed product" be under a precise control.

To our knowledge, the current study investigates the first application of 4matrix QFD method and its combination with GAHP to identify and develop the technical and qualitative characteristics of the meat products in accordance with the customers' requirements. There is no study in the
\end{abstract} \\ literature.
}

\section{Introduction}

In these times, considering the socio-cultural changes of human societies, fast foods are among items which have a high place in the food baskets. Hamburgers are among these products and are used by many people throughout the world. In Iran, hamburger is a mixture of beef, onion, rusk flour, garlic, and other additives and is produced in different foodstuff industries (Hajimohammadi et al., 2014). With the aim of identifying the type of additives of meat products and their amounts (Jiang and Xiong, 
2016) and packing methods of these products (Godziszewska et al., 2017; Hęś and GramzaMichałowska, 2016; Molina-Besch, 2016) several studies have been made and different countries have enforced standards and rules governing on foodstuff products (Moore et al., 2012; Rowe et al., 2004; Scramlin et al., 2010; Solomakos et al., 2008). However, in development and improvement of these standards and production processes, the demands and expectations of customers have not sufficiently been considered. Taking the customer requirements when drawing up the standards will make foodstuff factories to become more interested and eager to adapt and implement new hygienic rules in production of their products.

In the arena of competitive markets, emphasis has been put on expectations of customers and meeting them in the technical requirements of the product (Paiva and Pinto, 2012). Satisfying customer requirements and expectations and responding properly to the market changes are a prerequisite for companies to compete (Kazemzadeh et al., 2009).

Quality Function Deployment (QFD) is a suitable tool for translating the market requirements into the technical language used by designers and engineers (Kowalska et al., 2015) in different stages of production to answer the voice of customers (Jia and Bai, 2011). The concept of QFD was put forward for the first time in 1966 by Yoji Akao in Japan (Akao and Mazur, 2003). QFD includes three models: 4Matrix Model, 30-Matrix Model, and 3-Matrix Model (Revelle et al., 1998).

In recent years, QFD underwent different changes and has been combined with many techniques. Among them are: Fuzzy Logic, Kano model, AHP, analytic network process (ANP) and so forth (Sivasamy et al., 2016).

Year 1987 may be considered the beginning year of entering QFD into the world of foodstuff industries. Since then several researches have been published in which the application of QFD in foodstuff industries and its benefits, especially in respect of customer-oriented development, have been explained. In some of these researches, QFD was introduced as a suitable and promising method in facilitating foodstuff development process (Benner et al., 2003). Others, also have introduced QFD as a structured and useful approach to identify customers' needs and expectations from food products (Rudolph, 1995).

The technique has been used in different studies focusing on foodstuff industries. Dalen (1996) studied the capabilities of QFD and possibility of applying it to meat industry. Dalen's findings showed that with the help of QFD, one can find out the important and real demands of the customers in respect of the meat they consume. Accordingly, he took those needs in designing the techno-engineering characteristics of the final product. Waisarayutt and Tutiyapak (2006) studied and evaluated the capability of QFD in process development of a new type of macaroni with the help of crosscultural consumer characterization (4Cs) and sensory analysis. Mattsson and Helmersson (2007) reviewed customers' opinions about hamburger consumption in order to develop food products and then clustered these opinions by their approach, named text analytical approach. Sayadi et al. (2017) identified the consumers' expectations of olive oil, and reviewed 439 customers' opinions, to formed the House of Quality matrix, in order to incorporate them in the final product design.

QFD has been also used as a tool for increasing the sales amount of a type of probiotic macaroni's in the market (Pinto and Paiva, 2010); as a method for examining the degree of wheat flour customers' satisfaction (Kristianto et al., 2012); as a method for knowing the expectations who use a beefbearing food (Park et al., 2012); and for examining the production of organic products (de Fátima Cardoso et al., 2015). Also, Expansion of QFD and its combination with Fuzzy numbers has been investigated (Bevilacqua et al., 2012).

The related scientific sources can be reviewed in two aspects:

(1) Using QFD to develop the standards of meat and meat products: 
Among the studies, the application of QFD to develop the processes of meat and meat products can be observed in only 2 cases: The study of Dalen (1996) on the possibility of the implementation of OFD in meat industry, and the study of Park et al. (2012) on a detailed identification of the customers' demands for a food made from beef.

(2) 4-matrix approach of QFD

On the other hand, to find out the customers' needs of the foodstuff products, the 4-matrix technique has been used just in one study (Kowalska et al., 2015).

Perhaps, the scientists of foodstuff industries are not well aware of the principal aims of QFD and its potential in foodstuff products development (Costa et al., 2000). While more than half a century has been passed from the birth of QFD concept, the research and studies on foodstuff field still is limited (Benner et al., 2003).

In the literature there is probably no practical study to identify the customers' needs and expectations from fast foods, especially hamburgers, using the 4-matrix approach of QFD and to produce a product in accordance with the customer's taste. Whereas the consumption of these kinds of products shows a growing trend among various countries of the world (Bowman and Vinyard, 2004; Chiang et al., 2011; Jeffery et al., 2006; Majabadi et al., 2016).

The present study seeks to obviate the lack of a study that practically and operationally converts the opinions of a kind of fast food's consumers into the technical features and characteristics of the product. The aim of this study is thus to improve the production process of special $60 \%$ red meat-hamburger with the inclusion of customers' demands and to enhance its quality level by combining QFD and GAHP techniques.

\section{Materials and methods}

\subsection{QFD and its 4-Matrix model}

While there are differences between various QFD models, the logic and philosophy of all of them are the same and they have no aim but creating a clear and transparent relation between what the customers expect from a product and the product/service process. The 4-matrix approach will be able to answer all the questions about designing and production of a product. This approach can comprehensively review the features and characteristics of the required materials and components and also the manufacturing processes of a product. Besides, the requirements related to planning and control of manufacturing processes can be identified by this approach.

Considering that 4-Matrix model is more common than other models, this model is used in present study. Especially it provides a coverage on different stages of production (Revelle et al., 1998).

The weak point of QFD is that the numbers entered in its matrices may be inconsistent. However, if these numbers be calculated through Group Analytic Hierarchy Process (GAHP), we will not see this inconsistency.

\subsection{Group Analytic Hierarchy Process (GAHP) and Its Methodology}

Analytic Hierarchy Process is one of the multi-criteria decision making techniques. The technique was first introduced by Thomas L. Saaty (Saaty, 1980) .In this method, first a hierarchical structure of the problem is formed. In this structure, the aim is at the top and indices and alternatives are on other levels. After formation of the hierarchical structure, the indices undergo weighing observation in form of paired comparison first with each other and then with the alternatives. For judging about weighing paired comparison matrix, the quantitative value of 1 to 9 is used. After weighing observation, the weights must be normalized. Then, arithmetic means (relative weight) of all rows of normalized matrices of the paired comparisons are achieved. At the end, the resulted relative weights are multiplied by the arithmetic mean of the alternatives. Now, we can arrange alternatives in a list of priorities. In this technique, Inconsistent Rate (IR) of decision can always be calculated and the decision can be judged to be good or bad, and acceptable or 
unacceptable. In every system, the degree of acceptable inconsistency depends on its decision maker, but if the inconsistency degree is more than $1 \%$, the judgments shall be reconsidered. Therefore, calculation of inconsistency degree of paired comparisons matrix too is necessary. For this purpose, paired comparisons matrix (A) is multiplied by the relative weights $(\mathrm{W})$. The resulted vector is called Weighted Sum Vector (WSV). Then, Consistency Vector (CV) is resulted to be as follows (Golden et al., 1989):

$$
\begin{aligned}
W S V & =A \times W \\
C V & =\frac{W S V}{W}
\end{aligned}
$$

We call the average of consistency vector elements $\lambda_{\max }$ (the greatest Eigen Value of paired comparison matrix). Having $\lambda_{\max }$, the Inconsistence Index (II) and inconsistence rate for the group comparisons can be defined as follows (Golden et al., 1989):

$$
\begin{gathered}
I I=\frac{\lambda_{\max }-n}{n-1} \\
I R=\frac{I I}{I I R}
\end{gathered}
$$

The variable $n$ represents number of customers' demands which enter into QFD 4matrix models $(n=14)$ (Eq. 3). In scientific sources, the values of Inconsistency Index Random matrix (IIR) of differentn's have been calculated. Here, for $n=14$ the value of IIR is $1.57(\mathrm{IRR}=1.57)$ (Golden et al., 1989). In case we want to have the opinion of two or more decision makers about paired comparison, we have to resort to group decision making method. Saaty and Aczel have showed that geometric mean method is the best method for consolidating the judgments on group Analytic Hierarchy Process. Thus, geometric mean of the opinions of different experts $a_{i j}^{\prime}$ is defined as follows (Aczél and Saaty, 1983) (Eq. 5).

$$
\begin{aligned}
a_{i j}^{\prime} & =\left(\prod_{l}^{k} a_{i j l}\right)^{\frac{1}{k}} \\
l & =1,2, \ldots, k ; \\
i, j & =1,2, \ldots, n ; i \neq j
\end{aligned}
$$

In Equation $5, l$ is the code of the decision maker, $k$ is number of decision makers, and $i, j$ are the compared alternatives.

\subsection{Stages of the Research}

The steps taken in this research have been demonstrated in Figure 1.

\subsection{Case Study}

The case study for this research was made in Pak Taliseh Foodstuff Industries Company in year 2019. This company started its activities in year 1979 under trade name 202 and at present is one of the biggest producers of meat products in Iran.

\subsubsection{Recognizing the Customers and Their Demands}

At the beginning, QFD team was formed independently beyond the framework of Pak Taliseh Company organization. The duty of the team at first step was recognizing the base of desired customer. Holding several meetings with the experts and managers of the Company, the high volume of selling and expansion of activities were considered as criteria and as a result chain stores, supermarkets, sellers of ready-to-use foodstuffs, and restaurants were selected as base of desired customer. In continuation of studies, 25 demands that the customers expect from $60 \%$ red meathamburger were recognized. Then, the demands which were contrary to legal requirements and internal rules of the Company were eliminated, and so only 14 demands were selected for being entered into the House of Quality Matrix.

Table 1. Demands of the customers of $60 \%$ red meat-hamburger

\begin{tabular}{|c|c|}
\hline Demands & Classification \\
\hline In-between Paper of the Hamburger be separable Easily & \\
\cline { 1 - 1 } $\begin{array}{c}\text { The box of the purchased hamburger be not damp (has no wet } \\
\text { patch) }\end{array}$ & \\
\hline Production series be written on the box & \multirow{2}{*}{ Packaging Feature } \\
\hline Packed in different weights & \\
\hline
\end{tabular}


Soheylinia et al./ Carpathian Journal of Food Science and Technology, Special Issue 2020, 12(5), 167-180

\begin{tabular}{|c|c|}
\hline It shall be fresh & \multirow{2}{*}{ Reliability Feature } \\
\hline It shall have high durability & \\
\hline It shall be delicious & \multirow{6}{*}{ Qualitative Features } \\
\hline It shall not have bad color when cooked & \\
\hline It shall not be ill smelling & \\
\hline It shall be crisp and juicy & \\
\hline It shall not shrink when is being cooked & \\
\hline Not being harmful to body & \\
\hline The surface of raw hamburger shall be smooth & \multirow{2}{*}{ Appearance Features } \\
\hline The surface of raw hamburger shall not be dark & \\
\hline
\end{tabular}

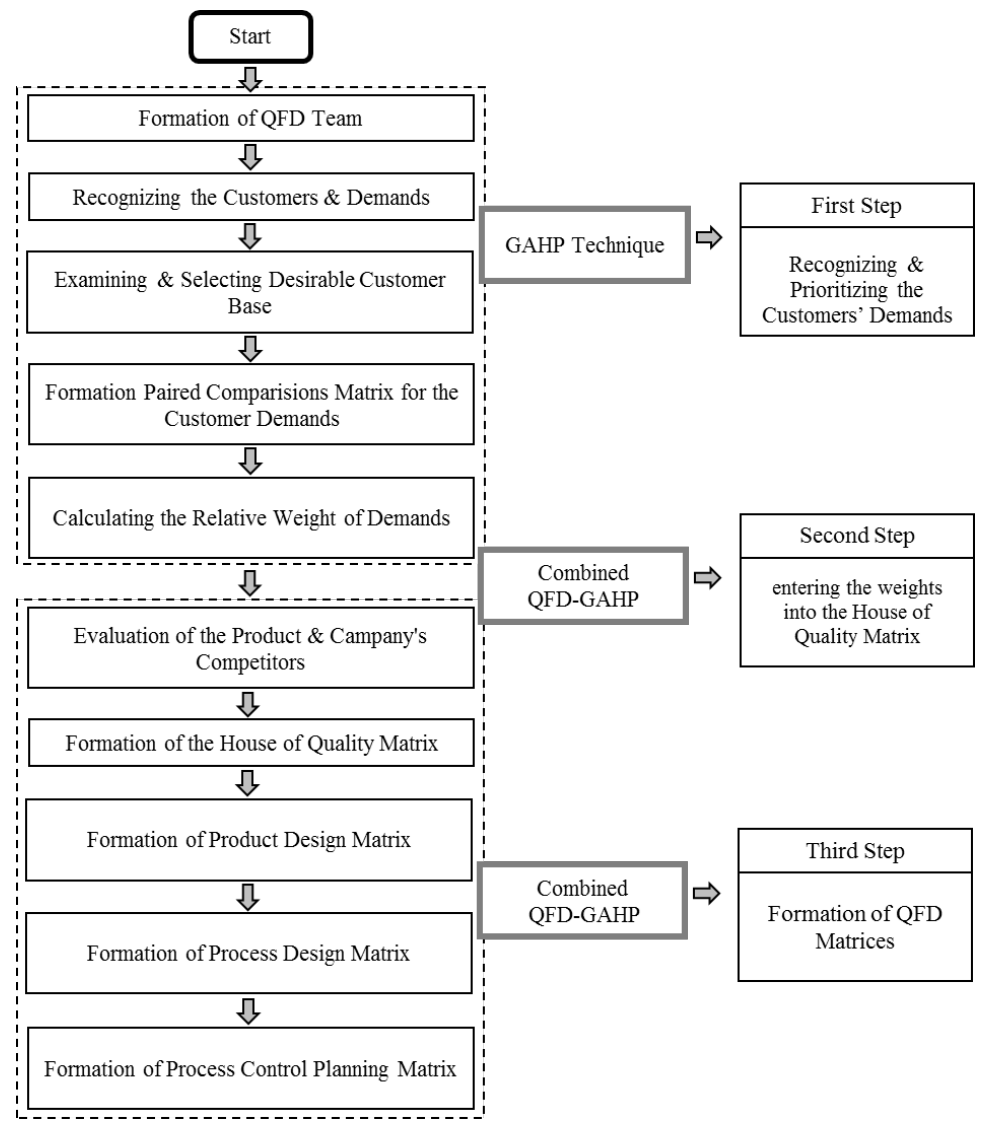

Figure 1. Steps of Combined QFD-GAHP Technique

\subsubsection{Calculation of Relative Weight of the Customer's Demands}

For allocating weights to the demands of customers, three proficient experts were consulted. The opinions of these three experts were equally considered. In the study, the paired comparisons were made in Expert Choice software and by using the qualitative values from 1 to 9 . Each expert provided separately one table for the paired comparisons of 14 demands of the customers (totally, 3 tables were provided). The final comparison table of the demands of the customers was drawn up by combining the comparison tables in geometric mean method. For brevity, only the final table is presented here. As an example, the number 0.5848 in Table 2 (first row, column 14) has been as displayed below (Eq. 6).

$$
\begin{gathered}
a_{i j}^{\prime}=\left(\prod_{l}^{k} a_{i j l}\right)^{\frac{1}{k}}=\left(\frac{1 \times 1 \times 1}{5}\right)^{\frac{1}{3}} \\
=0.5848
\end{gathered}
$$


Table 2. Final table the customers' demands comparison

\begin{tabular}{|c|c|c|c|c|c|c|c|c|c|c|c|c|c|c|}
\hline & 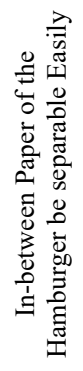 & 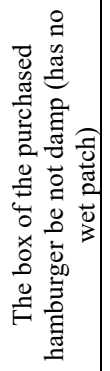 & 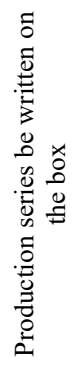 & 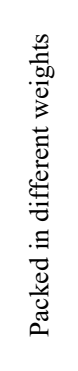 & 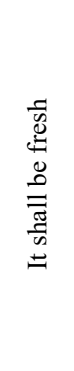 & 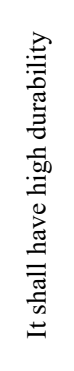 & 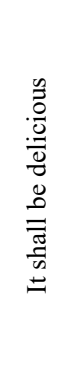 & 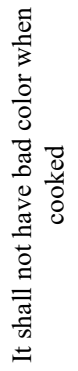 & 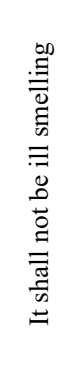 & 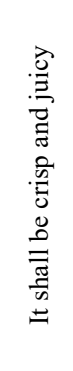 & 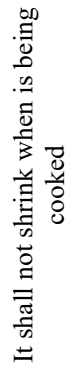 & 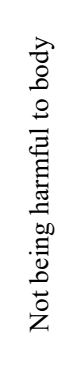 & 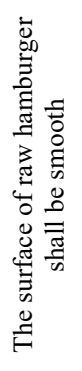 & 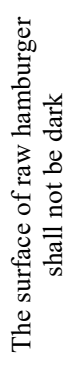 \\
\hline $\begin{array}{c}\text { In-between Paper of the } \\
\text { Hamburger be separable } \\
\text { Easily }\end{array}$ & 1 & 0.6300 & 0.8736 & 0.5848 & 0.1366 & 0.1598 & 0.1208 & 0.4368 & 0.1882 & 0.5503 & 0.7937 & 0.1383 & 1 & 0.5848 \\
\hline $\begin{array}{l}\text { The box of the purchased } \\
\text { hamburger be not damp (has } \\
\text { no wet patch) }\end{array}$ & 1.5874 & 1 & 3.1072 & 2.4101 & 0.1376 & 0.1682 & 0.1529 & 0.7469 & 0.1926 & 0.7211 & 0.9086 & 0.1314 & 1.9129 & 1.2051 \\
\hline $\begin{array}{l}\text { Production series be written } \\
\text { on the box }\end{array}$ & 1.1447 & 0.3218 & 1 & 1.4422 & 0.1682 & 0.1771 & 0.1682 & 0.4368 & 0.1598 & 0.2811 & 0.4368 & 0.1257 & 0.3218 & 0.4368 \\
\hline Packed in different weights & 0.6300 & 0.4149 & 0.6934 & 1 & 0.1314 & 0.1609 & 0.1156 & 0.3150 & 0.1598 & 0.2154 & 0.2554 & 0.1111 & 0.3684 & 0.2554 \\
\hline It shall be fresh & 7.3186 & 7.2685 & 5.9439 & 7.6117 & 1 & 1.2164 & 1 & 6.0822 & 1 & 3.2711 & 7.2304 & 0.2811 & 6.6039 & 6.6039 \\
\hline It shall have high durability & 6.2573 & 5.9439 & 5.6462 & 6.2145 & 0.8221 & 1 & 0.3420 & 5.3133 & 0.7937 & 4 & 4.3089 & 0.1682 & 3.9149 & 4.8203 \\
\hline It shall be delicious & 8.2768 & 6.5421 & 5.9439 & 8.6535 & 1 & 2.9240 & 1 & 7.5595 & 1 & 1.5874 & 1.5178 & 0.2811 & 6.6494 & 5.3133 \\
\hline $\begin{array}{l}\text { It shall not have bad color } \\
\text { when cooked }\end{array}$ & 2.2894 & 1.3389 & 2.2894 & 3.1748 & 0.1644 & 0.1882 & 0.1323 & 1 & 0.1598 & 1 & 1 & 0.1257 & 1 & 1.2599 \\
\hline It shall not be ill smelling & 5.3133 & 5.1925 & 6.2573 & 6.2573 & 1 & 1.2599 & 1 & 6.2573 & 1 & 6.2573 & 5.5934 & 0.1949 & 5.6462 & 5.6462 \\
\hline It shall be crisp and juicy & 1.8171 & 1.3867 & 3.5569 & 4.6416 & 0.3057 & 0.2500 & 0.6300 & 1 & 0.1598 & 1 & 1 & 0.1257 & 1 & 1 \\
\hline $\begin{array}{l}\text { It shall not shrink when is } \\
\text { being cooked }\end{array}$ & 1.2599 & 1.1006 & 2.2894 & 3.9149 & 0.1383 & 0.2321 & 0.1812 & 1 & 0.1788 & 1 & 1 & 0.1352 & 1.4422 & 1.2599 \\
\hline Not being harmful to body & 7.2304 & 7.6117 & 7.9581 & 9 & 3.5569 & 5.9439 & 3.5569 & 7.9581 & 5.1299 & 7.9581 & 7.3986 & 1 & 8.2768 & 7.3986 \\
\hline $\begin{array}{c}\text { The surface of raw } \\
\text { hamburger shall be smooth }\end{array}$ & 1 & 0.5228 & 3.1072 & 2.7144 & 0.1514 & 0.2554 & 0.1504 & 1 & 0.1771 & 1 & 0.6934 & 0.1208 & 1 & 1 \\
\hline $\begin{array}{l}\text { The surface of raw } \\
\text { hamburger shall not be dark }\end{array}$ & 1.7100 & 0.8298 & 2.2894 & 3.9149 & 0.1514 & 0.2075 & 0.1882 & 0.7937 & 0.1771 & 1 & 0.7937 & 0.1352 & 1 & 1 \\
\hline
\end{tabular}

Further, the inconsistency rate of the comparisons too shall be calculated. For this purpose, MATLAB software was used and $\lambda_{\max }$ $=14.9$ was resulted. According to Equations 3 and 4 we have IR $=0.044$. As interpretation of the value resulted for IR, one may say that since 0.044 is less than 0.1 thus the paired comparisons are consistent (Golden et al., 1989). Then, the weights were normalized. For normalization, each weight was divided by the total of the weights of same column. At the end, the arithmetic mean of each row of the new table was calculated and by so doing, the relative weight of each customer's demand was obtained. The relative weights were entered into the table 3 in order of their importance. Second step was entering the weight of each demand into the House of Quality Matrix. Then we started third step.

Table 3. Final table the customers' demands comparison

\begin{tabular}{|c|c|}
\hline Demands of Customers & Relative Weight \\
\hline Not being harmful to body & 0.2683 \\
\hline It shall be delicious & 0.1367 \\
\hline It shall be fresh & 0.1338 \\
\hline It shall not be ill smelling & 0.1249 \\
\hline It shall have high durability & 0.1024 \\
\hline It shall be crisp and juicy & 0.0382 \\
\hline $\begin{array}{c}\text { It shall not shrink when is being } \\
\text { cooked }\end{array}$ & 0.0308 \\
\hline
\end{tabular}


Soheylinia et al./ Carpathian Journal of Food Science and Technology, Special Issue 2020, 12(5), 167-180

\begin{tabular}{|c|c|}
\hline $\begin{array}{c}\text { It shall not have bad color when } \\
\text { cooked }\end{array}$ & 0.0304 \\
\hline $\begin{array}{c}\text { The box of the purchased } \\
\text { hamburger be not damp (has no } \\
\text { wet patch) }\end{array}$ & 0.0294 \\
\hline $\begin{array}{c}\text { The surface of raw hamburger } \\
\text { shall be smooth }\end{array}$ & 0.0289 \\
\hline $\begin{array}{c}\text { The surface of raw hamburger } \\
\text { shall not be dark }\end{array}$ & 0.0269 \\
\hline $\begin{array}{c}\text { In-between Paper of the } \\
\text { Hamburger be separable Easily }\end{array}$ & 0.0196 \\
\hline $\begin{array}{c}\text { Production series be written on } \\
\text { the box }\end{array}$ & 0.0167 \\
\hline Packed in different weights & 0.0130 \\
\hline
\end{tabular}

\subsubsection{Formation of QFD 4-Matrix Models}

At first stage of third step, the QFD team evaluated $60 \%$ red meat-hamburger produced by 2 companies, that is, Pak Taliseh Company and BA Company, with due regard to the demands of the customers and the qualitative requirements of the product expected by customers. For comparing the product of Pak Taliseh Company with product of BA Company, a scale from 1 (the worst) to 5 (the best) was used. Attention shall be made that Table 4 will enter into Evaluation of the Company column (Column N) and Table 5 in Evaluation of the Company's Competitors column (Column O) of
Table 6. For instance, the number 3.3019 in $12^{\text {th }}$ row has been extracted from Table 4 by $(3 \times 4 \times 3)^{(1 / 3)}=3.3019$ operation. After prioritization of the customers' demands and completion of Tables 4 and 5, the 4-matrix models were prepared while the principles governing their formation were regarded (Tables 6,7,8,9)(Revelle et al., 1998). In these tables, the symbol - represents number 9, symbol o represents number 3 , and symbol $\Delta$ is representative of number 1 .

Table 4. Evaluation of the hamburger produced by Pak Taliseh Company

$\left.\begin{array}{|c|c|}\hline \text { Demands of Customers } & \text { Relative Weight } \\ \hline \begin{array}{c}\text { In-between Paper of the Hamburger be } \\ \text { separable Easily }\end{array} & 3.9149 \\ \hline \begin{array}{c}\text { The box of the purchased hamburger be } \\ \text { not damp (has no wet patch) }\end{array} & 4.6416 \\ \hline \text { Production series be written on the box } & 1.2599 \\ \hline \text { Packed in different weights } & 4.6416 \\ \hline \text { It shall be fresh } & 4.3089 \\ \hline \text { It shall have high durability } & 4 \\ \hline \text { It shall be delicious } & 5 \\ \hline \text { It shall not have bad color when cooked } & 4.6416 \\ \hline \text { It shall not be ill smelling } & 5 \\ \hline \text { It shall be crisp and juicy } & 3.3019 \\ \hline \text { It shall not shrink when is being cooked } & 5 \\ \hline \text { Not being harmful to body } & 4.6416 \\ \hline \text { The surface of raw hamburger shall be } \\ \text { smooth }\end{array}\right)$

Table 5. Evaluation of the hamburger produced by BA Company

\begin{tabular}{|c|c|}
\hline Demands of Customers & Relative Weight \\
\hline $\begin{array}{c}\text { In-between Paper of the Hamburger be } \\
\text { separable Easily }\end{array}$ & 3.3019 \\
\hline
\end{tabular}


Soheylinia et al./ Carpathian Journal of Food Science and Technology, Special Issue 2020, 12(5), 167-180

\begin{tabular}{|c|c|}
\hline $\begin{array}{c}\text { The box of the purchased hamburger be } \\
\text { not damp (has no wet patch) }\end{array}$ & 5 \\
\hline Production series be written on the box & 3.3019 \\
\hline Packed in different weights & 1.5874 \\
\hline It shall be fresh & 2.5198 \\
\hline It shall have high durability & 4.6416 \\
\hline It shall be delicious & 2.5198 \\
\hline It shall not have bad color when cooked & 2.7144 \\
\hline It shall not be ill smelling & 3.9149 \\
\hline It shall be crisp and juicy & 2.8845 \\
\hline It shall not shrink when is being cooked & 3.9149 \\
\hline Not being harmful to body & 4.6416 \\
\hline $\begin{array}{c}\text { The surface of raw hamburger shall be } \\
\text { smooth }\end{array}$ & 3.3019 \\
\hline $\begin{array}{l}\text { The surface of raw hamburger shall not } \\
\text { be dark }\end{array}$ & 2.2894 \\
\hline
\end{tabular}

Table 6. the House of Quality Matrix of $60 \%$ red meat-hamburger

\begin{tabular}{|c|c|c|c|c|c|c|c|c|c|c|c|c|c|c|c|c|c|c|c|c|c|c|}
\hline & & & & & & & & & & & & & & & $\mathrm{A}$ & $\mathrm{N}$ & $\mathrm{O}$ & $\mathrm{P}$ & B & $\mathrm{C}$ & $\mathrm{D}$ & $\mathrm{E}$ \\
\hline $\begin{array}{l}\text { Engineering } \\
\text { Characteristics }\end{array}$ & 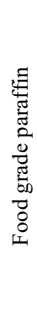 & 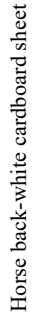 & 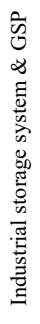 & 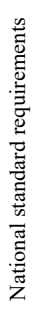 & 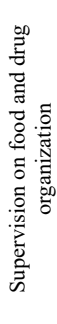 & 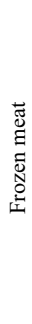 & 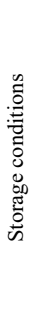 & 苋 & 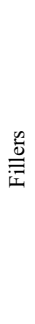 & 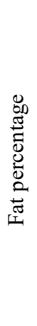 & 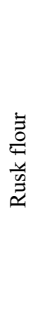 & 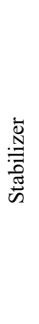 & 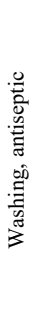 & 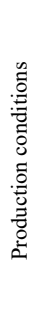 & 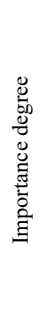 & 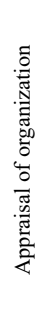 & 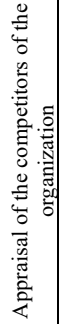 & 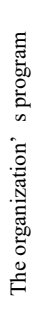 & 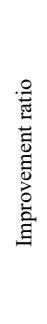 & 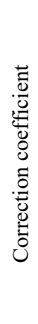 & $\begin{array}{l}\frac{7}{50} \\
.00 \\
0 \\
3 \\
0 \\
0 \\
0 \\
0 \\
0 \\
0\end{array}$ & 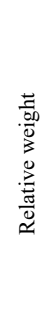 \\
\hline $\begin{array}{c}\text { In-between } \\
\text { Paper of the } \\
\text { Hamburger be } \\
\text { separable Easily }\end{array}$ & • & & & o & o & & & & & & & & & o & $\begin{array}{c}0.01 \\
96\end{array}$ & 4 & $\begin{array}{c}3.30 \\
19\end{array}$ & 5 & 1.25 & $1 / 2$ & $\begin{array}{c}0.02 \\
94\end{array}$ & $\begin{array}{c}1.879 \\
0\end{array}$ \\
\hline $\begin{array}{l}\text { The box of the } \\
\text { purchased } \\
\text { hamburger be } \\
\text { not damp (has } \\
\text { no wet patch) }\end{array}$ & & • & o & o & o & & • & & & & & & & $\Delta$ & $\begin{array}{c}0.02 \\
94\end{array}$ & $\begin{array}{c}3.91 \\
49\end{array}$ & 5 & 4 & $\begin{array}{c}1.02 \\
17\end{array}$ & $1 / 2$ & $\begin{array}{c}0.03 \\
60\end{array}$ & $\begin{array}{c}2.300 \\
9\end{array}$ \\
\hline $\begin{array}{c}\text { Production } \\
\text { series be written } \\
\text { on the box }\end{array}$ & & & • & $\Delta$ & o & & & & & & & & & & $\begin{array}{c}0.01 \\
67\end{array}$ & $\begin{array}{c}4.64 \\
16\end{array}$ & $\begin{array}{c}3.30 \\
19\end{array}$ & 3 & $\begin{array}{c}0.64 \\
63\end{array}$ & 1 & $\begin{array}{c}0.01 \\
07\end{array}$ & $\begin{array}{c}0.683 \\
8\end{array}$ \\
\hline $\begin{array}{c}\text { Packed in } \\
\text { different weights }\end{array}$ & & & & o & • & & & & & & & & & & $\begin{array}{c}0.01 \\
30 \\
\end{array}$ & $\begin{array}{c}1.25 \\
99 \\
\end{array}$ & $\begin{array}{l}1.58 \\
74 \\
\end{array}$ & 3 & $\begin{array}{c}2.38 \\
11 \\
\end{array}$ & 1 & $\begin{array}{c}0.03 \\
09 \\
\end{array}$ & $\begin{array}{c}1.974 \\
9 \\
\end{array}$ \\
\hline It shall be fresh & & & $\cdot$ & o & • & • & • & $\bullet$ & o & $\Delta$ & • & $\Delta$ & & o & $\begin{array}{c}0.13 \\
38\end{array}$ & $\begin{array}{c}4.64 \\
16\end{array}$ & $\begin{array}{c}2.51 \\
98\end{array}$ & 5 & $\begin{array}{c}1.07 \\
72\end{array}$ & $1 / 5$ & $\begin{array}{c}0.21 \\
61\end{array}$ & $\begin{array}{c}13.81 \\
18\end{array}$ \\
\hline $\begin{array}{c}\text { It shall have } \\
\text { high durability }\end{array}$ & & & o & • & - & • & • & o & • & o & o & • & $\cdot$ & & $\begin{array}{c}0.10 \\
24 \\
\end{array}$ & $\begin{array}{c}4.30 \\
89 \\
\end{array}$ & $\begin{array}{c}4.64 \\
16 \\
\end{array}$ & 5 & $\begin{array}{c}1.16 \\
03 \\
\end{array}$ & $1 / 5$ & $\begin{array}{c}0.17 \\
82 \\
\end{array}$ & $\begin{array}{c}11.38 \\
94 \\
\end{array}$ \\
\hline $\begin{array}{l}\text { It shall be } \\
\text { delicious }\end{array}$ & & & & • & o & • & & $\cdot$ & • & • & $\cdot$ & o & & & $\begin{array}{c}0.13 \\
67 \\
\end{array}$ & 4 & $\begin{array}{c}2.51 \\
98 \\
\end{array}$ & 5 & 1.25 & $1 / 5$ & $\begin{array}{c}0.25 \\
63 \\
\end{array}$ & $\begin{array}{c}16.38 \\
11 \\
\end{array}$ \\
\hline $\begin{array}{l}\text { It shall not have } \\
\text { bad color when } \\
\text { cooked }\end{array}$ & & & • & $\Delta$ & $\Delta$ & • & • & o & o & $\bullet$ & o & o & $\Delta$ & & $\begin{array}{c}0.03 \\
04\end{array}$ & 5 & $\begin{array}{c}2.71 \\
44\end{array}$ & 5 & 1 & $1 / 2$ & $\begin{array}{c}0.03 \\
64\end{array}$ & $\begin{array}{c}2.326 \\
4\end{array}$ \\
\hline $\begin{array}{c}\text { It shall not be ill } \\
\text { smelling }\end{array}$ & & & $\Delta$ & o & o & • & o & $\cdot$ & • & $\bullet$ & $\cdot$ & $\bullet$ & o & o & $\begin{array}{c}0.12 \\
49 \\
\end{array}$ & $\begin{array}{c}4.64 \\
16 \\
\end{array}$ & $\begin{array}{c}3.91 \\
49 \\
\end{array}$ & 5 & $\begin{array}{c}1.07 \\
72 \\
\end{array}$ & $1 / 5$ & $\begin{array}{c}0.20 \\
18 \\
\end{array}$ & $\begin{array}{c}12.89 \\
78 \\
\end{array}$ \\
\hline $\begin{array}{l}\text { It shall be crisp } \\
\text { and juicy }\end{array}$ & & & & o & & • & & & • & • & $\cdot$ & • & & & $\begin{array}{c}0.03 \\
82 \\
\end{array}$ & 5 & $\begin{array}{c}2.88 \\
45 \\
\end{array}$ & 5 & 1 & $1 / 5$ & $\begin{array}{c}0.05 \\
73 \\
\end{array}$ & $\begin{array}{c}3.662 \\
2 \\
\end{array}$ \\
\hline $\begin{array}{l}\text { It shall not } \\
\text { shrink when is } \\
\text { being cooked }\end{array}$ & & & & o & & o & o & & • & $\bullet$ & o & • & & • & $\begin{array}{c}0.03 \\
08\end{array}$ & $\begin{array}{c}3.30 \\
19\end{array}$ & $\begin{array}{c}3.91 \\
49\end{array}$ & 4 & $\begin{array}{l}1.21 \\
14\end{array}$ & $1 / 2$ & $\begin{array}{c}0.04 \\
47\end{array}$ & $\begin{array}{c}2.856 \\
9\end{array}$ \\
\hline $\begin{array}{c}\text { Not being } \\
\text { harmful to body }\end{array}$ & • & o & • & $\bullet$ & • & • & • & $\cdot$ & • & • & $\cdot$ & • & $\bullet$ & • & $\begin{array}{c}0.26 \\
83 \\
\end{array}$ & 5 & $\begin{array}{c}4.64 \\
16 \\
\end{array}$ & 5 & 1 & $1 / 5$ & $\begin{array}{c}0.40 \\
24 \\
\end{array}$ & $\begin{array}{c}25.71 \\
90 \\
\end{array}$ \\
\hline $\begin{array}{l}\text { The surface of } \\
\text { raw hamburger } \\
\text { shall be smooth }\end{array}$ & & o & o & & & $\mathrm{o}$ & • & & o & & & & & • & $\begin{array}{c}0.02 \\
69\end{array}$ & $\begin{array}{c}4.64 \\
16\end{array}$ & $\begin{array}{c}3.30 \\
19\end{array}$ & 4 & $\begin{array}{c}0.86 \\
17\end{array}$ & $1 / 2$ & $\begin{array}{c}0.02 \\
98\end{array}$ & $\begin{array}{c}1.904 \\
6\end{array}$ \\
\hline $\begin{array}{l}\text { The surface of } \\
\text { raw hamburger } \\
\text { shall not be dark }\end{array}$ & & & o & $\Delta$ & $\Delta$ & • & o & o & o & o & o & o & & • & $\begin{array}{c}0.02 \\
89\end{array}$ & 5 & $\begin{array}{c}2.84 \\
94\end{array}$ & 5 & 1 & $1 / 2$ & $\begin{array}{c}0.03 \\
46\end{array}$ & $\begin{array}{c}2.211 \\
4\end{array}$ \\
\hline
\end{tabular}




\begin{tabular}{|c|c|c|c|c|c|c|c|c|c|c|c|c|c|c|c|c|c|c|c|}
\hline \multicolumn{2}{|c|}{ Target Value } & 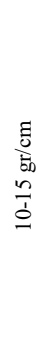 & 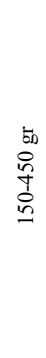 & & & & 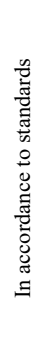 & $\begin{array}{l}0 \\
0 \\
\infty \\
1\end{array}$ & 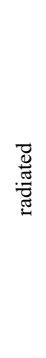 & 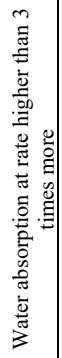 & 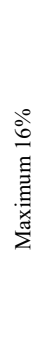 & 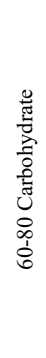 & 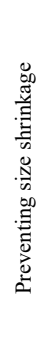 & 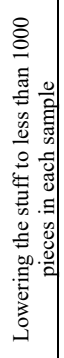 & 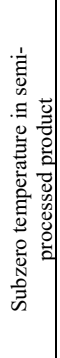 & 嵒 & 焉 & $\begin{array}{l}\text { fơ } \\
\text { ñ } \\
\end{array}$ & \& \\
\hline \multirow{2}{*}{$\begin{array}{c}\text { Weig } \\
\text { ht }\end{array}$} & $\begin{array}{c}\text { Absolu } \\
\text { te } \\
\text { weight }\end{array}$ & $\begin{array}{c}2.59 \\
11\end{array}$ & $\begin{array}{c}1.15 \\
02\end{array}$ & $\begin{array}{c}4.90 \\
69\end{array}$ & $\begin{array}{c}5.81 \\
17\end{array}$ & $\begin{array}{c}5.698 \\
7\end{array}$ & $\begin{array}{c}7.94 \\
55\end{array}$ & $\begin{array}{c}5.87 \\
46\end{array}$ & $\begin{array}{c}6.45 \\
84\end{array}$ & $\begin{array}{c}6.97 \\
17\end{array}$ & $\begin{array}{c}6.19 \\
14\end{array}$ & $\begin{array}{c}6.89 \\
46\end{array}$ & $\begin{array}{c}5.80 \\
32\end{array}$ & $\begin{array}{c}3.74 \\
14\end{array}$ & $\begin{array}{c}5.25 \\
36\end{array}$ & $\begin{array}{c}75.2 \\
93\end{array}$ & & & \\
\hline & $\begin{array}{c}\text { Relativ } \\
\mathrm{e} \\
\text { weight( } \\
\%)\end{array}$ & $\begin{array}{c}3.44 \\
14\end{array}$ & $\begin{array}{c}1.52 \\
76\end{array}$ & $\begin{array}{c}6.51 \\
71\end{array}$ & $\begin{array}{c}7.56 \\
87\end{array}$ & $\begin{array}{c}10.55 \\
28\end{array}$ & $\begin{array}{c}7.80 \\
23\end{array}$ & $\begin{array}{c}8.57 \\
77\end{array}$ & $\begin{array}{c}9.25 \\
94\end{array}$ & $\begin{array}{c}8.22 \\
31\end{array}$ & $\begin{array}{c}9.15 \\
70\end{array}$ & $\begin{array}{c}7.70 \\
75\end{array}$ & $\begin{array}{c}4.96 \\
91\end{array}$ & $\begin{array}{c}6.97 \\
75\end{array}$ & $\begin{array}{c}6.97 \\
75\end{array}$ & 100 & & & \\
\hline
\end{tabular}

Table 7. Product design matrix of $60 \%$ red meat-hamburger

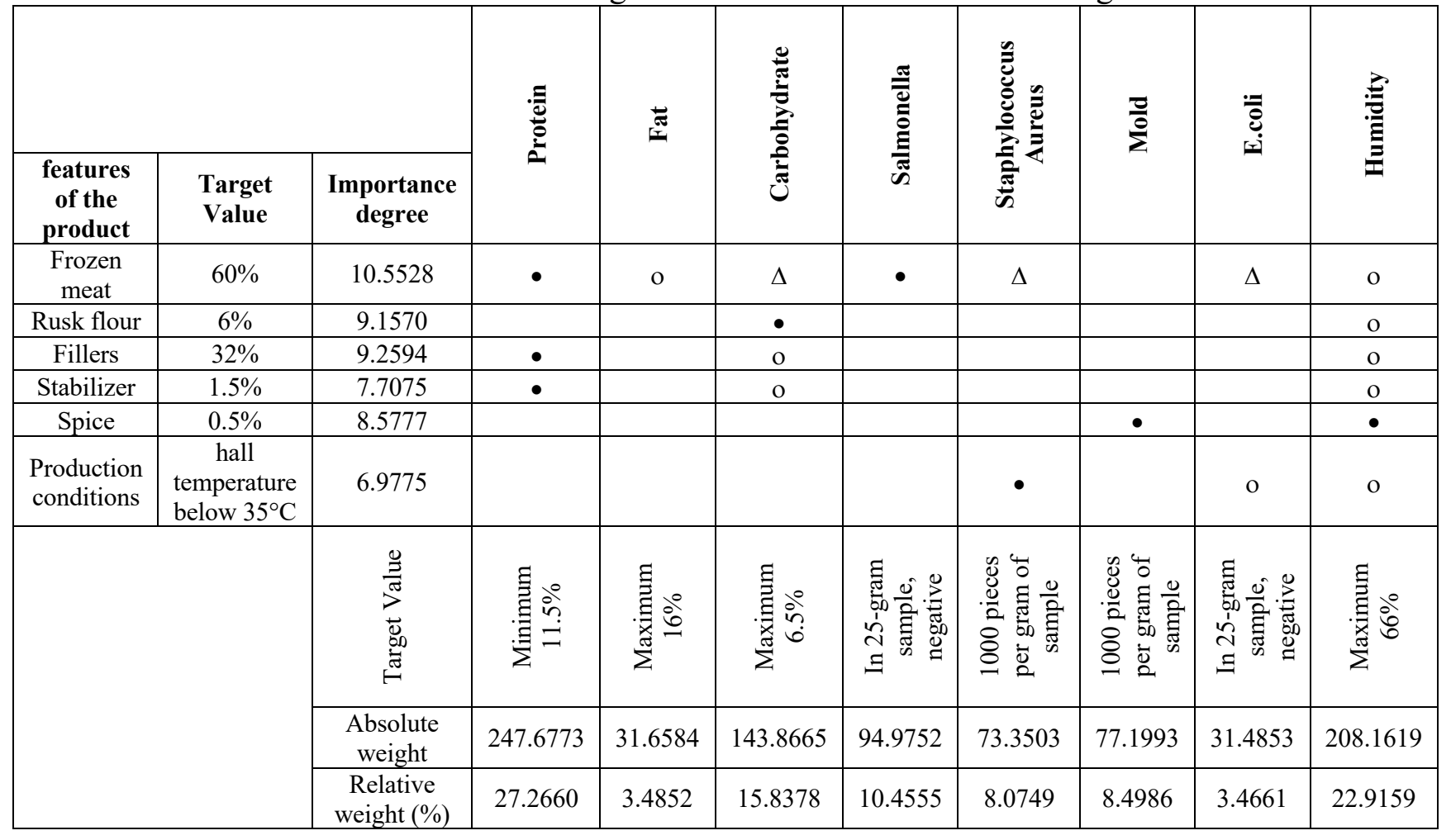

Table 8. Process design matrix of $60 \%$ red meat-hamburger

\begin{tabular}{|c|c|c|c|c|c|c|c|c|c|c|c|c|c|c|}
\hline & & & \multicolumn{6}{|c|}{ Inspection and entrance control } & \multicolumn{6}{|c|}{ During-process control } \\
\hline & & & \multirow{2}{*}{ 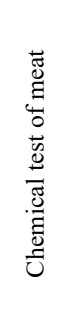 } & \multirow{2}{*}{ 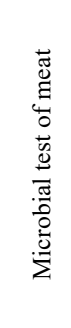 } & \multirow{2}{*}{ 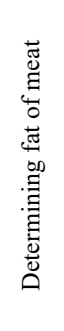 } & \multirow{2}{*}{ 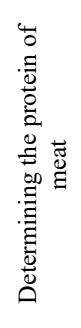 } & \multirow{2}{*}{ 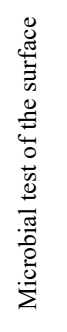 } & \multirow{2}{*}{ 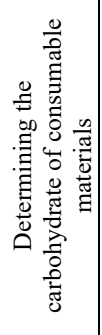 } & \multirow{2}{*}{ 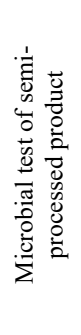 } & \multirow{2}{*}{ 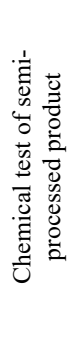 } & \multirow{2}{*}{ 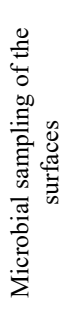 } & \multirow{2}{*}{ 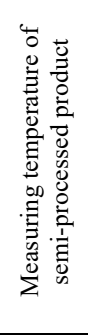 } & \multirow{2}{*}{ 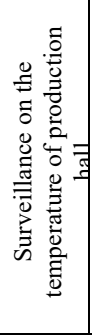 } & \multirow{2}{*}{ 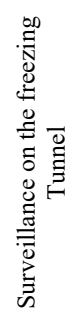 } \\
\hline $\begin{array}{l}\text { Features } \\
\text { of the } \\
\text { ingredie } \\
\text { nts }\end{array}$ & $\begin{array}{c}\text { Targe } \\
\mathbf{t} \\
\text { Value }\end{array}$ & $\begin{array}{c}\text { Import } \\
\text { ance } \\
\text { degree }\end{array}$ & & & & & & & & & & & & \\
\hline
\end{tabular}


Soheylinia et al./ Carpathian Journal of Food Science and Technology, Special Issue 2020, 12(5), 167-180

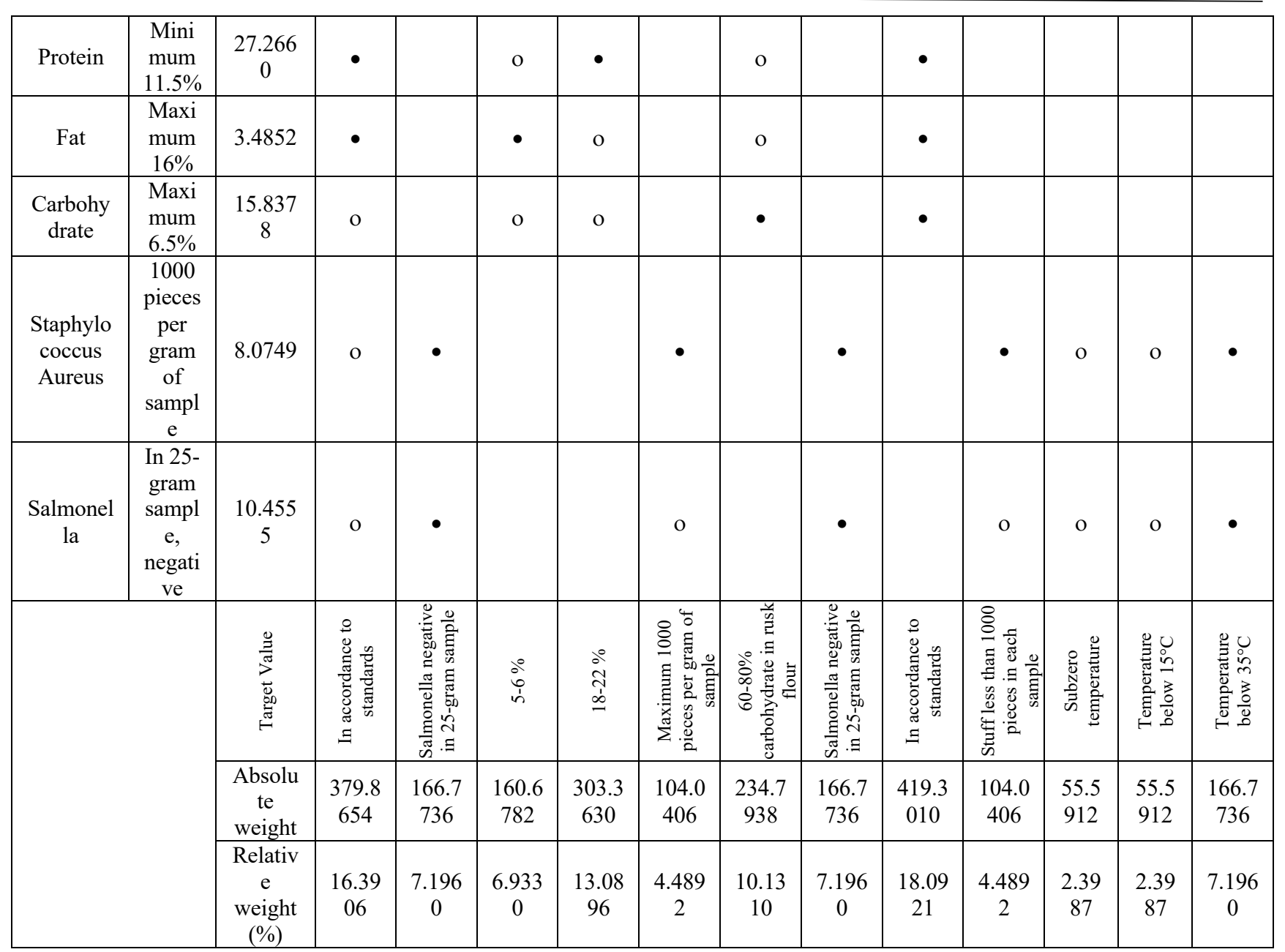

Table 9. Process control planning matrix of $60 \%$ red meat-hamburger

\begin{tabular}{|c|c|c|c|c|c|c|c|c|c|c|c|c|c|c|c|c|}
\hline \multirow[b]{2}{*}{ 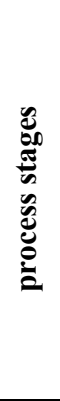 } & \multirow[b]{2}{*}{ key needs of the process } & \multirow[b]{2}{*}{ 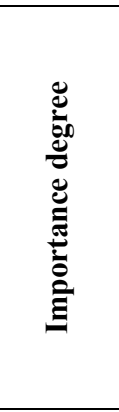 } & \multicolumn{5}{|c|}{ evaluation of operation } & \multicolumn{9}{|c|}{ planning needs } \\
\hline & & & 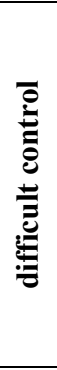 & 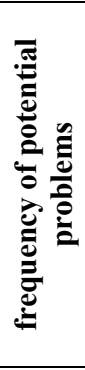 & 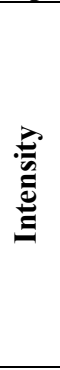 & 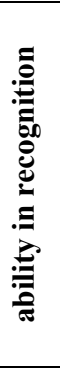 & 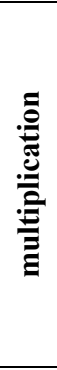 & 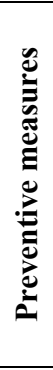 & 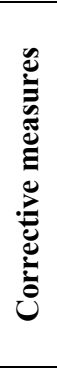 & 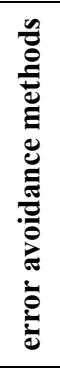 & 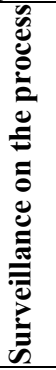 & 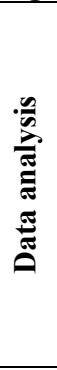 & 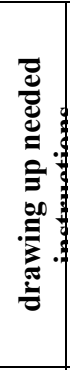 & 兑 & 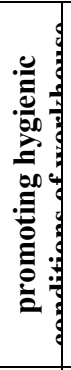 & 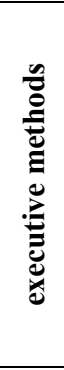 \\
\hline \multirow{6}{*}{ 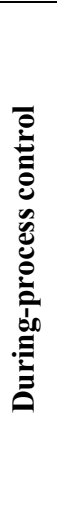 } & $\begin{array}{l}\text { Surveillance on the } \\
\text { temperature of freezing } \\
\text { tunnel }\end{array}$ & 7.1960 & 3 & 2 & 2 & 1 & 12 & $\sqrt{ }$ & $\sqrt{ }$ & $\sqrt{ }$ & & & & & $\sqrt{ }$ & \\
\hline & $\begin{array}{c}\text { Surveillance on the } \\
\text { temperature of production } \\
\text { hall }\end{array}$ & 2.3987 & 1 & 1 & 1 & 1 & 1 & $\sqrt{ }$ & $\sqrt{ }$ & & & & & & $\sqrt{ }$ & \\
\hline & $\begin{array}{l}\text { Measuring temperature of } \\
\text { semi-processed product }\end{array}$ & 2.3987 & 1 & 1 & 1 & 1 & 1 & & & & $\sqrt{ }$ & & & & & \\
\hline & $\begin{array}{c}\text { Microbial sampling of the } \\
\text { surfaces }\end{array}$ & 4.4892 & 2 & 2 & 2 & 1 & 8 & & & $\sqrt{ }$ & $\sqrt{ }$ & $\sqrt{ }$ & & $\sqrt{ }$ & $\sqrt{ }$ & $\sqrt{ }$ \\
\hline & $\begin{array}{l}\text { Chemical test of semi- } \\
\text { processed product }\end{array}$ & 18.0921 & 1 & 1 & 1 & 1 & 1 & & & $\sqrt{ }$ & $\sqrt{ }$ & $\sqrt{ }$ & $\sqrt{ }$ & & & $\sqrt{ }$ \\
\hline & $\begin{array}{l}\text { Microbial test of semi- } \\
\text { processed product }\end{array}$ & 7.1960 & 3 & 3 & 2 & 1 & 18 & & & $\sqrt{ }$ & $\sqrt{ }$ & $\sqrt{ }$ & $\checkmark$ & & & $\sqrt{ }$ \\
\hline
\end{tabular}


Soheylinia et al./ Carpathian Journal of Food Science and Technology, Special Issue 2020, 12(5), 167-180

\begin{tabular}{|c|c|c|c|c|c|c|c|c|c|c|c|c|c|c|c|}
\hline $\begin{array}{c}\text { Determining the } \\
\text { carbohydrate of consumable } \\
\text { materials }\end{array}$ & 10.1310 & 1 & 1 & 1 & 1 & 1 & & & & & $\sqrt{ }$ & $\sqrt{ }$ & & $\sqrt{ }$ \\
\hline $\begin{array}{c}\text { Microbial test of the surface } \\
\text { metermining the protein of }\end{array}$ & 4.4892 & 2 & 2 & 2 & 1 & 8 & $\sqrt{ }$ & $\sqrt{ }$ & & $\sqrt{ }$ & & $\sqrt{ }$ & $\sqrt{ }$ & $\sqrt{ }$ \\
\hline
\end{tabular}

\section{Results and discussions}

In this section, the results of using Combined QFD-GAHP approach are presented in Figure 1.

\subsection{The Results Earned from the House of Quality Matrix}

In the first matrix, called the House of Quality Matrix (Table 6), in the column of "the Degree of Importance" the highest weight was for "It shall not be harmful to body" with 0.2683. This requirement is strongly linked to 13 items out of totally 14 items of engineering characteristics. Among engineering characteristics, "frozen meat" with absolute weight of 7.9455, was the most important. It is highly related to the qualitative features of "It shall be fresh", "It shall have high durability", "It shall not have bad color when cooked", "It shall not be ill smelling", "It shall be crispy and juicy", "It shall not be harmful to body", "It shall be delicious", and "The surface of raw hamburger shall not be dark". Therefore, improvement of the quality of frozen meat has a great effect on meeting these eight customer needs.

\subsection{Results of the Product Design Matrix}

In product design matrix (Table 7), improvement of quality of "frozen meat" depends on the levels set for "protein" and "salmonella". In this matrix, the most important feature of hamburger relates to "protein" (with absolute weight of 247.6773) and the least important one relates to "E.coli" (with absolute weight of 31.4853 ).

\subsection{Results of the Process Design Matrix and the Process Control Planning Matrix}

In process design matrix (Table 8 ), the most important in-process controlling feature relates to "chemical test of semi-processed product" (with absolute weight of 419.301) and the least important ones are "surveillance on the temperature of production hall" and "measuring the temperature of semi-processed product" (each with absolute weight of 55.5912. Since in process control planning matrix (Table 9), both "microbial test of meat" and "microbial test of semi-processed product" have an appraisal level of 18 (column of multiplication), therefore performing these two tests are more necessary than other requirements. For "surveillance on the temperature of freezing tunnel", "surveillance on the temperature of production hall" and "microbial test of surfaces", corrective and preventive actions are also needed.

Considering the fourth QFD matrix, using error avoidance methods for issues such as surveillance on the temperature of freezing tunnel, microbial sampling of the surface, chemical test of semi-processed product, microbial test of semi-processed product, determining the protein of meat, microbial test of meat, and chemical test of meat is unavoidable. Similarly, the necessary actions for surveillance on the process, data analysis, drawing up needed instructions, training, promoting hygienic conditions of workhouse, and "executive methods" maybe defined.

\subsection{Findings of Other Studies}

The findings of Dalen's study (1996) indicated that QFD technique is a suitable tool for converting the customers' needs to technical features of the final product. The findings of Waisarayutt and Tutiyapak (2006) indicate that more detailed needs of customers may be discovered with help of 4Cs and then enter them into QFD matrices.. There is only one study (Mattsson and Helmersson, 2007) that has analyzed and prioritized the customers' 
feedbacks about the Hamburger consumption. In this article, the Customers' opinions are classified into 4 clusters and 2 general categories of "taste" and "ingredients" of the product. The results represented that the customers' opinions are largely in accordance with the concept of what is known as the standard hamburger.

The articles of Dalen's (1996); Waisarayutt and Tutiyapak (2006); and Mattsson and Helmersson, (2007), have reported QFD as a suitable technique to identify customers' needs and expectations from products, but none of these articles has even designed and completed its matrices. Meanwhile, there was only one article (Mattsson and Helmersson, 2007) about hamburger. In this research, although surveying and clustering the consumers' views about a type of hamburger were studied, but no approach was proposed in order to produce and develop a product based on customer expectations. On the contrary, the present study could well develop the product designing to production stage, by the QFD-GAHP mixed approach based on the requirements of customers.

Among the reviewed articles, only two papers (Sayadi et al., 2017) (Kowalska et al., 2015) have provided the QFD matrices. Sayyadi et al, has provided only the first matrix, and kowalska et al. (2015), has completed all of the four matrices. This is despite the fact that the research field of both of these studies was not the meat industry and products. Instead, the present paper has formed all of the four matrices of QFD in accordance with the technical principles and hygienic standards laid down in the meat products industry. On the other hand, the simultaneous use of the opinions of some experts in completing the paired comparisons matrix and eliminating the inconsistency of them was another feature of this study.

\section{Conclusions}

In present study, for promoting the quality of $60 \%$ red meat-hamburger, a combined QFDGAHP technique was used. This approach had a significant impact on the designing to production stages of new hamburgers, with QFD 4-Matrix Models and group analytical hierarchy by the elimination of inconsistency in the pairwise comparison matrix.

The demand of "It shall not be harmful to body" and the engineering characteristics of "frozen meat" were respectively the most important requirement and the engineering characteristic of hamburger. The results of this study showed that the improvement of the "protein" and "salmonella" characteristics would be two of key factors in improving the quality of "frozen meat". Also, "microbial test of meat" and "microbial test of semi-processed product" were reported as the most important control characteristics during the process.

Finally, the point which is noteworthy is that QFD 4-Matrix Model was able to consider the qualitative requirements of customers in all stages of hamburger production from designing to production. The study made valuable information about the customers and engineering features of hamburger accessible to QFD team engaged in our case study. The method used in this research, may be used successfully in development and enhancing the quality of other meat products. Mitigating the risk of product rejection by customers, more selling in market, and decreasing the costs such as quality costs and costs of reworks are among the benefits of using QFD in the foodstuff researches.

\section{References}

Aczel, J. \& Saaty, T. L. (1983). Procedures for synthesizing ratio judgements, Journal of Mathematical Psychology, 27 (1), 93-102.

Akao, Y. \& Mazur, G. H. (2003). The leading edge in QFD: past, present and future, International Journal of Quality \& Reliability Management, 20(1), 20-35.

Benner, M., Linnemann, A. R., Jongen, W. M. F. \& Folstar, P. (2003). Quality function deployment (qfd)-can it be used to develop food products? Food Quality and Preference, 14(4), 327-339.

Bevilacqua, M., Ciarapica, F. E. \& Marchetti, B. (2012). Development and test of a new fuzzy-qfd approach for characterizing 
customers rating of extra virgin olive oil. Food Quality and Preference, 24(1), 75-84.

Bowman, S. A. \& Vinyard, B. T. (2004). Fast food consumption of US adults: impact on energy and nutrient intakes and overweight status. Journal of the American College of Nutrition, 23(2), 163-168.

Chiang, P.-H., Wahlqvist, M. L., Lee, M.-S., Huang, L.-Y., Chen, H.-H. \& Huang, S. T.Y. (2011). Fast-food outlets and walkability in school neighbourhoods predict fatness in boys and height in girls: a Taiwanese population study, Public Health Nutrition. 14(9), 1601-1609.

Costa, A., Dekker, M. \& Jongen, W. (2000). Quality function deployment in the food industry: a review, Trends in Food Science \& Technology. 11(9), 306-314.

Dalen, G. A. (1996). Assuring eating quality of meat, Meat Science, 43, 21-33.

De fatima cardoso, J., casarotto filho, N. \& miguel, P. A. C. (2015). Application of quality function deployment for the development of an organic product. Food Quality and Preference, 40, 180-190.

Godziszewska, J., Guzek, D., Glabska, D., Jozwik, A., Brodowska, M., Glabski, K., Zarodkiewicz, M., Gantner, M. \& Wierzbicka, A. (2017). Nutrient oxidation in pork loin is influenced by feed supplementation and packing methods. Journal of Food Composition and Analysis, $56,18-24$.

Golden, B. L., Wasil, E. A. \& Harker, P. T. (1989). The analytic hierarchy process, applications and studies, Springer, Berlin, Heidelberg.

Hajimohammadi, B., Dehghani, A., Ahmadi, M. M., Eslami, G., oryan, A. \& Khamesipour, A. (2014). Prevalence and species identification of sarcocystis in raw hamburgers distributed in yazd, iran using pcr-rflp. Journal of Food Quality and Hazards Control, 1(1)15-20.

Hes, M. \& Gramza-michalowska, A. (2017). Effect of plant extracts on lipid oxidation and changes in nutritive value of protein in frozen-stored meat products. Journal of
Food Processing and Preservation. 41(3), 12989.

Jeffery, R. W., Baxter, J., Mcguire, M. \& Linde, J. (2006). Are fast food restaurants an environmental risk factor for obesity? International Journal of Behavioral Nutrition and Physical Activity. 3(1), 2.

Jia, G. \& Bai, M. (2011). An approach for manufacturing strategy development based on fuzzy-qfd, Computers \& Industrial Engineering. 60(3), 445-454.

Jiang, J. \& Xiong, Y. L. (2016). Natural antioxidants as food and feed additives to promote health benefits and quality of meat products: A review. Meat Science, 120, 107117.

Kazemzadeh, R., Behzadian, M., Aghdasi, M. \& Albadvi, A. (2009). Integration of marketing research techniques into house of quality and product family design, The International Journal of Advanced Manufacturing Technology. 41(9), 10191033.

Kowalska, M., Pazdzior, M. \& Krzton-Maziopa, A. (2018). Implementation of qfd method in quality analysis of confectionery products. Journal of Intelligent Manufacturing, 29(2), 439-447.

Kristianto, Y., Ajmal, M. M. \& Sandhu, M. (2012). Adopting tqm approach to achieve customer satisfaction: A flour milling company case study. The TQM Journal, 24(1)29-46.

Kristin, D., Morgan, L., Fangny, D., Sara, R., Caleb, W., Mallory, M., Andrew-White, L. W. T., Colin, D. W. (2010). Acute glycemic and blood lipid response to the ingestion of a candy bar-like protein supplement compared to its candy bar counterpart. Journal of the International Society of Sports Nutrition, 7(1), 1.

Majabadi, H. A., Solhi, M., Montazeri, A., Shojaeizadeh, D., Nejat, S., Farahani, F. K. \& Djazayeri, A. (2016). Factors influencing fast-food consumption among adolescents in tehran: A qualitative study. Iranian Red Crescent Medical Journal, 18(3). 
Mattsson, J. \& Helmersson, H. (2007). Food product development: A consumer-led text analytic approach to generate preference structures. British Food Journal, 109(3), 246-259.

Molina-Besch, K. (2016). Prioritization guidelines for green food packaging development. British Food Journal. 118(10), 2512-2533.

Moore, M. C., Gray, G., Hale, D., Kerth, C., Griffin, D., Savell, J., Raines, C., Belk, K., Woerner, D. \& Tatum, J. (2012). National beef quality audit-2011: In-plant survey of targeted carcass characteristics related to quality, quantity, value, and marketing of fed steers and heifers, Journal of Animal Science. 90(13), 5143-5151.

Paiva, C. L. \& Pinto, A. L. D. (2012). Employment of the quality function deployment (qfd) method in the development of food products, INTECH Open Access Publisher.

Park, S.-H., Ham, S. \& Lee, M.-A. (2012). How to improve the promotion of Korean beef barbecue, bulgogi, for international customers. An application of quality function deployment. Appetite, 59(2) 324332.

Pinto, A. L. D. \& Paiva, C. L. (2010). Desenvolvimento de uma massa funcional pronta para tortas utilizando o método de desdobramento da função qualidade (qfd). Food Science and Technology (Campinas), 30(1) 36-43.

Revelle, J. B., Moran, J. W. \& Cox, C. A. (1998). The QFD Handbook, John Wiley \& Sons.

Rowe, L., Maddock, K., Lonergan, S. M. \& Huff-Lonergan, E. (2004). Influence of early postmortem protein oxidation on beef quality. Journal of Animal Science, 82(3), 785-793.

Rudolph, M. J. (1995). The food product development process. British Food Journal, 97(3) 3-11.

Saaty, T. L. (1980). The analytic hierarchy process, McGraw-Hill Book Company, New York.

Sayadi, S., Erraach, Y., \& Parra-Lopez, C. (2017). Translating consumer's olive-oil quality-attribute requirements into optimal olive-growing practices: A quality function deployment (qfd) approach. British Food Journal, 119(1), 190-214.

Scramlin, S. M., Newman, M. C., Cox, R. B., Sepe, H. A., Alderton, A. L., O'Leary, J. \& Mikel, W. B. (2010). Effects of oregano oil brine enhancement on quality attributes of beef longissimus dorsi and semimembranosus muscles from various age animals, Journal of Food Science, 75(2), 89-94.

Sivasamy, K., Arumugam, C., Devadasan, S., Murugesh, R. \& Thilak, V. (2016). Advanced models of quality function deployment: a literature review. Quality \& Quantity, 50(3), 1399-1414.

Solomakos, N., Govaris, A., Koidis, P. \& Botsoglou, N. (2008). The antimicrobial effect of thyme essential oil, nisin, and their combination against listeria monocytogenes in minced beef during refrigerated storage. Food Microbiology, 25(1), 120-127.

Waisarayutt, C. and Tutiyapak, O., (2006). Application of quality function deployment in instant rice noodle product development. Kasetsart Journal, 40, 162-171. 